\title{
Effects of cattle manure compost combined with chemical fertilizer on topsoil organic matter, bulk density and earthworm activity in a wheat-maize rotation system in Eastern China
}

\author{
Liyue Guo ${ }^{\mathrm{a}, \mathrm{b}, 1}$, Guanglei Wu ${ }^{\mathrm{a}, 1}$, Yong $\mathrm{Li}^{\mathrm{c}}$, Caihong $\mathrm{Li}^{\mathrm{a}}$, Wenjing Liu ${ }^{\mathrm{d}}$, Jie Menga \\ Haitao Liu ${ }^{\mathrm{a}}$, Xiaofan Yu ${ }^{\mathrm{a}, \mathrm{b}}$, Gaoming Jiang ${ }^{\mathrm{a}, *}$ \\ a State Key Laboratory of Vegetation and Environment Change, Institute of Botany, Chinese Academy of Sciences, 20 Nanxincun, Xiangshan, Beijing 100093, \\ China

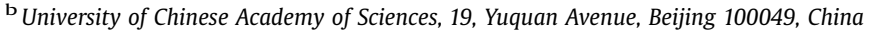 \\ ${ }^{\mathrm{c}}$ Key Laboratory of Ecosystem Network Observation and Modeling, Institute of Geographic Sciences and Natural Resources Research, Chinese Academy of \\ Sciences, 11A, Datun Road, Chaoyang District, Beijing 100101, China \\ d State Key Laboratory of Environmental Criteria and Risk Assessment, Chinese Research Academy of Environmental Sciences, 8 Anwai Dayangfang, Beijing \\ 100012, China
}

\section{A R T I C L E I N F O}

\section{Article history:}

Received 22 January 2015

Received in revised form 15 August 2015

Accepted 19 October 2015

Available online 9 November 2015

\section{Keywords:}

Cattle manure compost

Chemical fertilizer

Soil organic matter

Soil bulk density

Soil water content

Earthworm activity

\begin{abstract}
A B S T R A C T
Cattle manure compost (CMC) combined with chemical fertilizer (CF) was applied to a wheat-maize rotation field, in Eastern China, to assess soil physical and chemical properties, biological activity and land productivity. Indicators of organic matter, carbon storage and sequestration, bulk density, water content, total $\mathrm{N}$ content and earthworm population from topsoil $(0-20 \mathrm{~cm})$ were quantified. This consecutive study (2009-2014) was carried out on the base of the same total N, P, K application rate $(375.0 \mathrm{~kg}$ $\mathrm{Nha}^{-1} \mathrm{yr}^{-1}, 92.4 \mathrm{~kg} \mathrm{P}_{2} \mathrm{O}_{5} \mathrm{ha}^{-1} \mathrm{yr}^{-1}$ and $316.3 \mathrm{~kg} \mathrm{~K}_{2} \mathrm{O} \mathrm{ha}^{-1} \mathrm{yr}^{-1}$ ) in each treatment that was fertilized. Six treatments were designed as: (1) CK, without any fertilizer; (2) NPK, 100\% CF; (3) NPKM1, 25\% CMC combined with 75\% CF; (4) NPKM2, 50\% CMC combined with 50\% CF; (5) NPKM3, 75\% CMC combined with $25 \% \mathrm{CF}$; and (6) CM, $100 \% \mathrm{CMC}$. The results demonstrated that organic matter, water content, total $\mathrm{N}$ content and earthworm density from topsoil were significantly and positively $(P \leq 0.01)$ related to CMC input, with significantly negative correlation being observed between soil bulk density and CMC input. The average annual yield of the wheat-maize rotation system significantly increased $(P \leq 0.05)$ in NPK, NPKM1, NPKM2, NPKM3, and CM compared with CK, with the highest yield being obtained from NPKM1. Applying merely $\mathrm{CF}$ not only led to the lower SOM, water content and total $\mathrm{N}$ content, but also resulted in negative effects on earthworm activity, while CMC alleviated such negative effects. Our finding may help to increase food supply by improving soil conditions with organic fertilizer compost application.
\end{abstract}

(c) 2015 Elsevier B.V. All rights reserved.

\section{Introduction}

Soil organic matter (SOM) content is generally regarded as one of the key indicators of soil quality (Riley et al., 2008). Maintaining adequate amount of SOM is particularly important for sustaining the productivity of an agro-ecosystem (Lal et al., 1999; Carter, 2002; Ding et al., 2012). Numerous studies have found strong correlations among soil structure, soil aggregate stability and SOM content (Darwish et al., 1995; Haynes and Naidu, 1998). For instance, some studies have shown that increase in SOM improves

\footnotetext{
* Corresponding author. Fax: +8610 62590815

E-mail address: jgm@ibcas.ac.cn (G. Jiang).

1 These authors are equal to this work.
}

soil's aggregation, total porosity, hydraulic conductivity, waterholding capacity, resistance to water and wind erosion, and lowers bulk density and the degree of compaction (Celik et al., 2004; Leroy et al., 2008). Otherwise, a decline in SOM content increased soil compaction which has a negative impact on root growth through reducing the supply of water and nutrients (Martinez and Zinck, 2004; Celik et al., 2010). Bulk density is largely related with soil compaction, which alters the air-soil and water-soil interactions then further affects microbiological activity, nutrient uptake and water retention (Abu-Hamdeh, 2003; Martinez and Zinck, 2004). Soil organic matter retains water and helps soil particles to bind and resist against soil compaction (Celik et al., 2010). Preserving an adequate amount of SOM stabilizes soil structure which makes the soil more resistant to degradation (Thomas et al., 1996). Excess use 
of chemical fertilizers, however, has resulted in a significant depletion of SOM and serious water and soil pollution (Liu et al., 2003a,b; Minuto et al., 2006; Zhao et al., 2006; Li et al., 2007; Ju et al., 2009; Zhen et al., 2014). Serious losses of SOM have deteriorated soil quality and crop productivity, which has spurred scientist to explore ways to restore SOM (Liu et al., 2010; Ding et al., 2011). Studies have shown that maintaining SOM at optimum level can be achieved by fertilization practices (Zebarth et al., 1999; Wu et al., 2004; Yang et al., 2005; Blair et al., 2006; Verma and Sharma, 2007; Purakayastha et al., 2008; Gong et al., 2009). However, perhaps as cost saving measure, more and more chemicals have been added to soils, which would further degrade soil quality. Researchers therefore urgently needed to continue investigating management practices that can reduce soil degradation.

It is well documented that earthworm can maintain and improve soil fertility, soil structure and aggregate stability, nutrient cycling as well as plant productivity (Edwards and Lofty, 1977; Clements et al., 1991; Marinissen, 1994; Smetak et al., 2007; Riley et al., 2008). The experimentally induced absence of earthworms in grassland was found to increase soil bulk density and shear strength, greatly reduce SOM, pH, soil moisture and initial infiltration rate (Clements et al., 1991). Mineral fertilizers may have positive effects on earthworms by increasing the amount of plant biomass, thereby increasing their food supply (Edwards and Lofty, 1982). But the soil pH must be regulated to avoid negative effects of acidifying fertilizers (Ma et al., 1990). Organic fertilizers, such as animal manure, can also provide food for and increase the biomass of earthworms (Andersen, 1979). For instance, organic cropping systems have displayed higher earthworm biomass and density than conventional ones (Mäder et al., 2002). However, less is known how the long term application of organic manure combined with chemical fertilizer $(\mathrm{CF})$ will affect the soil biodiversity.

Usage of organic materials, such as sewage sludge, crop residues, compost and poultry manure, are well known to be beneficial practices in soil restoration (Tejada and Gonzales, 2008; Tejada et al., 2008). A long-term fertilizer experiment in paddy soil derived from barren land in subtropical China showed that applying CF in combination with farmyard manure increased SOM content more significantly than using CF alone (Li et al., 2010). However, organic inputs at normal level $\left(2-4.5 \mathrm{Mg} \mathrm{ha}^{-1}\right)$ in Northeastern China did not yield remarkable effects on restoring SOM level (Li et al., 2002). Although some found higher level of organic inputs could lead to a corresponding increase in soil carbon sequestration, they only evaluated the effects of organic fertilizer on soil properties at different rates or focused on adding organic fertilizer on the basis of CFapplication rates. On one hand, they did not consider the nutrients $(\mathrm{N}, \mathrm{P}, \mathrm{K})$ in organic fertilizer, and the fact that the total nutrients were not the same among treatments. On the other hand, not all chemical fertilizers were fully utilized. As excess use of CFalone has resulted in numerous negative effects, it is necessary to find the suitable application rates of organic materials mixed with CF.

Organic fertilizers release nutrients over time. On the basis of the same level nutrients (N, P, K), we want to know the effects of increased organic fertilizer combined with decreased $\mathrm{CF}$ on yield, soil characteristics and biological activity. Although earthworm activity is considered to be a biological indicator of soil quality (Doran and Zeiss, 2000), information is limited on the impact of using a mix of inorganic and organic fertilizers as treatments. We therefore hypothesized that utilizing a mix of inorganic and organic fertilizer could improve the soil quality, make the soil suitable for earthworms to live and achieve high crop yield in the long term. So in the present study, our objectives were to: (1) assess crop yield; (2) evaluate the changes in topsoil carbon storage and sequestration, and bulk density under different organic fertilization application rates; and (3) assess the effects of increased organic fertilizer combined with decreased $C F$ at various rates on earthworm activity. We hope the findings from this experiment can help to increase food supply while reducing possible chemical fertilization pollutions through organic fertilizer compost application.

\section{Materials and methods}

\subsection{Experimental site}

The field experiment was conducted at the Eco-farm Research Station of Shandong Agricultural University, based in Pingyi County, Shandong Province, Eastern China $\left(35^{\circ} 26^{\prime} 21^{\prime \prime} \mathrm{N}\right.$, $\left.117^{\circ} 50^{\prime} 11^{\prime \prime} \mathrm{E}\right)$. It was initiated on 25 September, 2009 . The study area experiences a typical temperate and monsoonal climate, with the mean annual rainfall being $770 \mathrm{~mm}$ and average annual temperature $13.2{ }^{\circ} \mathrm{C}$. The daily rainfall from 1 October, 2013 to 9 October, 2014 was listed in Fig. 1. The soil is Alfisols, according to the soil taxonomy (IUSS Working Group WRB, 2014). The main cropping system is winter wheat (Triticum aestiviumL.)-summer maize (Zea maysL.) rotation. Winter wheat grows from early October to early June of the following year and summer maize from middle June to early October. At the beginning of the experiment, the topsoil $(0-20 \mathrm{~cm}$ ) had a $\mathrm{pH}$ of 6.12 (soil:water $=1: 2.5$ ) and contained $7.40 \mathrm{~g} \mathrm{C} \mathrm{kg}^{-1}$ soil and $0.74 \mathrm{~g} \mathrm{~N} \mathrm{~kg}^{-1}$ soil. The soil bulk density was $1.43 \mathrm{~g} \mathrm{~cm}^{-3}$.

\subsection{Preparation of cattle manure compost}

Cattle manure was obtained from the nearby Hongyi Organic Farm, in Jiang Jiazhuang Village of Pingyi County. It was shaped into cuboids with width $1.5 \mathrm{~m}$, height $0.5 \mathrm{~m}$, with moisture content of $70 \%$. The compost was covered with plastic film, stirred and mixed every 20 days. After 90 days, the resulting cattle manure compost (CMC) was applied into the fields before sowing. The manure compost contained organic matter $40.61 \%$, total nitrogen $(\mathrm{N}) 2.11 \%$, total phosphorus $\left(\mathrm{P}_{2} \mathrm{O}_{5}\right) 0.52 \%$, total potassium $\left(\mathrm{K}_{2} \mathrm{O}\right) 1.78 \%$ and had moisture content of $68.9 \%$.

\subsection{Experimental design}

The treatments were arranged as: (1) CK, without any fertilizer; (2) NPK, 100\% chemical fertilizer (CF); (3) NPKM1, 25\% CMC combined with 75\% CF; (4) NPKM2, 50\% CMC combined with 50\% CF; (5) NPKM3, 75\% CMC combined with 25\% CF; (6) CM, $100 \%$ CMC.

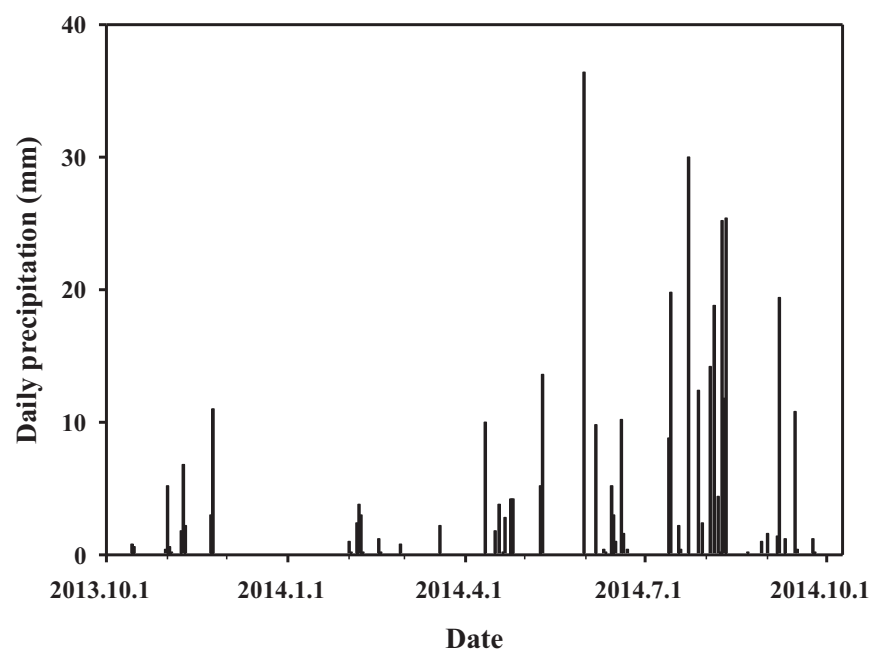

Fig. 1. The daily precipitation from 1 October, 2013 to 9 October, 2014 in the study area, Jiang Jiazhuang Village, Pingyi County, Eastern China. 
Except CK, the remainder five treatments had the same total N, P and $\mathrm{K}$ application rate of $375.0 \mathrm{~kg} \mathrm{~N} \mathrm{ha}^{-1} \mathrm{yr}^{-1}, 92.4 \mathrm{~kg} \mathrm{P}_{2} \mathrm{O}_{5} \mathrm{ha}^{-1}$ $\mathrm{yr}^{-1}$ and $316.3 \mathrm{~kg} \mathrm{~K}_{2} \mathrm{O} \mathrm{ha} \mathrm{hr}^{-1}$. However, parts of $\mathrm{N}, \mathrm{P}$ and $\mathrm{K}$ application were from different sources, e.g., urea $(\mathrm{N}=46.4 \%)$ as the chemical $\mathrm{N}$ source; superphosphate $\left(\mathrm{P}_{2} \mathrm{O}_{5}=12 \%\right)$ as the chemical $\mathrm{P}$ source; potassium sulphate $\left(\mathrm{K}_{2} \mathrm{O}=51 \%\right)$ as the chemical $\mathrm{K}$ source. The application rates of $\mathrm{CMC}$ and $\mathrm{CF}$ in the different treatments are listed in Table 1.

All the treatments were arranged in a randomized complete block design with three replicates (plot size $2.4 \mathrm{~m} \times 16 \mathrm{~m}$ ). Winter wheat was seeded between 15 and 20 October, and harvested around 5 June. Then summer maize was seeded $7 \mathrm{~d}$ later, four rows per plot being seeded. After harvest, all above-ground crop residues were removed from the field. It is historically common that CMC was homogenously spread out on the soil surface only after summer maize harvest; therefore all plots were ridged by rotary tillage before winter wheat seeding. There was no tillage before summer maize seeding in the experimental area.

\subsection{Sampling}

At wheat maturity, three replications of total plants in a quadrate area $(2.4 \mathrm{~m} \times 1 \mathrm{~m})$ were selected randomly for measuring wheat grain yield in each plot. When maize was harvested, three replications of 15 consecutive plants in the second row were selected randomly for estimating corn grain yield.

Soil samples were collected from surface layers $(0-20 \mathrm{~cm}$ soil depth) of each plot on 7 October, 2014. Five random subsamples in the same plot were pooled together, placed in polyethylene bags, and transported to the laboratory immediately. In the laboratory, all visible roots, cattle manure and plant fragments were removed. The composite samples were passed through a $2-\mathrm{mm}$ sieve. The sample was air-dried and ground to pass a $0.25-\mathrm{mm}$ sieve for total organic carbon and total nitrogen analysis.

Earthworm population was quantified on 13 June and 9 October, 2014 with three replications being done. Earthworms were handsorted from three soil cubes $(30 \mathrm{~cm} \times 30 \mathrm{~cm} \times 20 \mathrm{~cm}$ depth $)$ at each plot then the density and fresh biomass of earthworms were recorded.

\subsection{Chemical analysis}

Total soil organic carbon (SOC) was determined following dichromate oxidation procedure. Multiplying the SOC by 1.72 resulted in the SOM content (Nelson and Sommers, 1982). SOC storage at the $0-20 \mathrm{~cm}$ depth was calculated from horizon thickness and soil bulk density. The amount of sequestered organic carbon in $0-20 \mathrm{~cm}$ soil depth was determined after deducting the carbon storage that had occurred just before the start of the experiment. Total nitrogen was determined by the Kjeldahl Method (Bremner and Mulvaney, 1982).

Bulk density was determined on undisturbed soil samples using a steel cylinder of $100 \mathrm{~cm}^{3}$ volume $(5 \mathrm{~cm}$ in diameter, and $5.1 \mathrm{~cm}$ in height) for soil depths of both $0-10 \mathrm{~cm}$ and $10-20 \mathrm{~cm}$ separately. The bulk density was calculated by dividing the weight of the dried soil by the volume of the soil (Blake and Hartge, 1986).

Ten grams soil from $0-10 \mathrm{~cm}$ and $10-20 \mathrm{~cm}$ layers were sampled to be oven-dried at $105^{\circ} \mathrm{C}$ for $48 \mathrm{~h}$ to measure the soil water content on 11 June and 9 October, 2014 when were close to the sowing date for summer maize and winter wheat, respectively, and there was no rainfall during the previous two weeks. As adequate amount of soil water content is important for seed germination, if the soil water content was lower, pipe irrigation was practically applied. The $\mathrm{pH}$ was measured in a $1: 2.5(\mathrm{w} / \mathrm{v})$ soil/water suspension using a digital $\mathrm{pH}$ meter (PB-10, Sartorius, Germany).

\subsection{Statistical analysis}

Statistical analysis was performed using the software SPSS 17.0. All data were analyzed using one-way analysis of variance (ANOVA) and the least significance difference (LSD) test was used to establish if the differences in the treatments were significant at $P \leq 0.05$ level. Figures were generated using Sigmaplot 10.0 (Systat Software Inc.).

\section{Results and discussion}

3.1. Soil organic matter, average annual yield, soil organic carbon storage and sequestration

The 5-year application of cattle manure compost (CMC) combined with chemical fertilizer (CF) at various rates had statistically significant effect on SOM content as well as SOC content (Table 2). Compared with CK, SOM in all the plots fertilized with CMC has been increased $(P \leq 0.05)$ by $28 \%, 46 \%, 74 \%$, and $87 \%$ at $0-20 \mathrm{~cm}$ soil depth, with the greatest SOM content being noted in soil fertilized with CMC alone. CF had no statistically significant effect $(P>0.05)$ on SOM accumulation (Table 2$)$.

The average annual yield of the wheat-maize rotation system significantly increased $(P \leq 0.05)$ in NPK, NPKM1, NPKM2, NPKM3, and $\mathrm{CMC}$ compared with $\mathrm{CK}$, but showed no significant differences among the five treatments of inorganic fertilizer and CMC mixture. Nevertheless, the highest yield occurred in the plots fertilized with 25\% CMC combined with75\% CF (Table 2).

Different treatments also displayed significant influences on both soil organic carbon storage and sequestration. Organic carbon storage in the top soil $(0-20 \mathrm{~cm})$ was found to be significantly higher in NPKM1, NPKM2, NPKM3, and CM than that in CK and NPK $(P \leq 0.05)$. Both soil organic carbon storage and sequestration were

Table 1

Experiment design and application rates of organic manure and chemical fertilizer in different treatments.

\begin{tabular}{|c|c|c|c|c|c|c|c|}
\hline \multirow[t]{3}{*}{ Treatments } & \multicolumn{4}{|l|}{ Winter wheat } & \multicolumn{3}{|c|}{ Summer maize } \\
\hline & \multirow{2}{*}{$\begin{array}{l}\text { Cattle manure compost } \\
\left(\mathrm{kg} \mathrm{ha}^{-1}\right) \text { (dry weight) }\end{array}$} & \multicolumn{3}{|c|}{ Chemical fertilizer $\left(\mathrm{kg} \mathrm{ha}^{-1}\right)$} & \multicolumn{3}{|c|}{ Chemical fertilizer $\left(\mathrm{kg} \mathrm{ha}^{-1}\right)$} \\
\hline & & Urea & Superphosphate & Potassium sulphate & Urea & Superphosphate & Potassium sulphate \\
\hline CK & 0 & 0 & 0 & 0 & 0 & 0 & 0 \\
\hline NPK & 0 & 484.9 & 385.1 & 310.1 & 323.3 & 385.1 & 310.1 \\
\hline NPKM1 & 4443 & 363.7 & 288.8 & 232.6 & 242.5 & 288.8 & 232.6 \\
\hline NPKM2 & 8886 & 242.5 & 192.5 & 155.1 & 161.6 & 192.5 & 155.1 \\
\hline NPKM3 & 13329 & 121.2 & 96.3 & 77.5 & 80.8 & 96.3 & 77.5 \\
\hline $\mathrm{CM}$ & 17773 & 0 & 0 & 0 & 0 & 0 & 0 \\
\hline
\end{tabular}

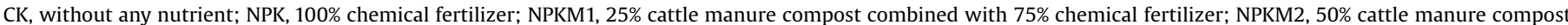
combined with $50 \%$ chemical fertilizer; NPKM3, $75 \%$ cattle manure compost combined with $25 \%$ of chemical fertilizer; CM, $100 \%$ cattle manure compost. 
Table 2

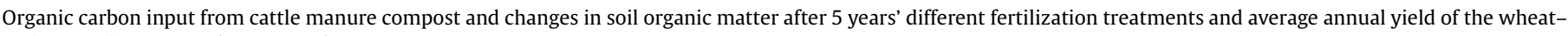
maize rotation system (2010-2014)

\begin{tabular}{|c|c|c|c|c|}
\hline Treatments & $\begin{array}{l}\text { Organic carbon input from cattle manure compost } \\
\left(\mathrm{kg} \mathrm{ha}^{-1} \mathrm{year}^{-1}\right)\end{array}$ & Soil organic carbon (\%) & Soil organic matter (\%) & Average annual yield $\left(\mathrm{kg} \mathrm{ha}^{-1}\right.$ year $\left.^{-1}\right)$ \\
\hline CK & 0 & $0.78 \pm 0.02 \mathrm{e}$ & $1.34 \pm 0.04 \mathrm{e}$ & $6466 \pm 1079.0 \mathrm{~b}$ \\
\hline NPK & 0 & $0.82 \pm 0.03 \mathrm{e}$ & $1.41 \pm 0.05 \mathrm{e}$ & $13872 \pm 1076.9 \mathrm{a}$ \\
\hline NPKM1 & 1804 & $0.99 \pm 0.01 \mathrm{~d}$ & $1.71 \pm 0.01 \mathrm{~d}$ & $14274 \pm 1555.7 \mathrm{a}$ \\
\hline NPKM2 & 3609 & $1.13 \pm 0.02 \mathrm{c}$ & $1.95 \pm 0.03 \mathrm{c}$ & $13451 \pm 1125.9 \mathrm{a}$ \\
\hline NPKM3 & 5413 & $1.35 \pm 0.01 \mathrm{~b}$ & $2.33 \pm 0.02 \mathrm{~b}$ & $12430 \pm 1469.7 \mathrm{a}$ \\
\hline $\mathrm{CM}$ & 7217 & $1.46 \pm 0.01 \mathrm{a}$ & $2.51 \pm 0.03 \mathrm{a}$ & $11551 \pm 1508.0 \mathrm{a}$ \\
\hline
\end{tabular}

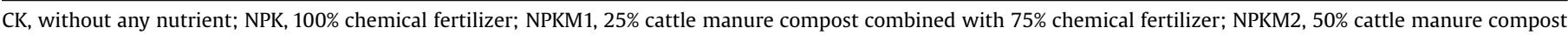

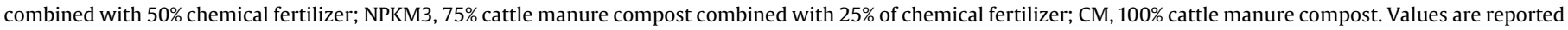
as means \pm standard deviations, $n \geq 3$. Different letters within each column show significant differences at $P \leq 0.05$.

found to be considerably higher in the plots fertilized with only CMC. Although no statistical differences appeared in soil organic carbon storage and sequestration between NPK and CK, both soil organic carbon storage and sequestration were slightly higher in the former treatment (Fig. 2).

Our finding clearly supports the hypothesis that organic fertilization has positive impacts on SOM, soil organic carbon storage and sequestration. In this study, the above-ground biomass was removed from field plots, so there were no crop residues incorporated into the soil. Thus the input of organic carbon mainly

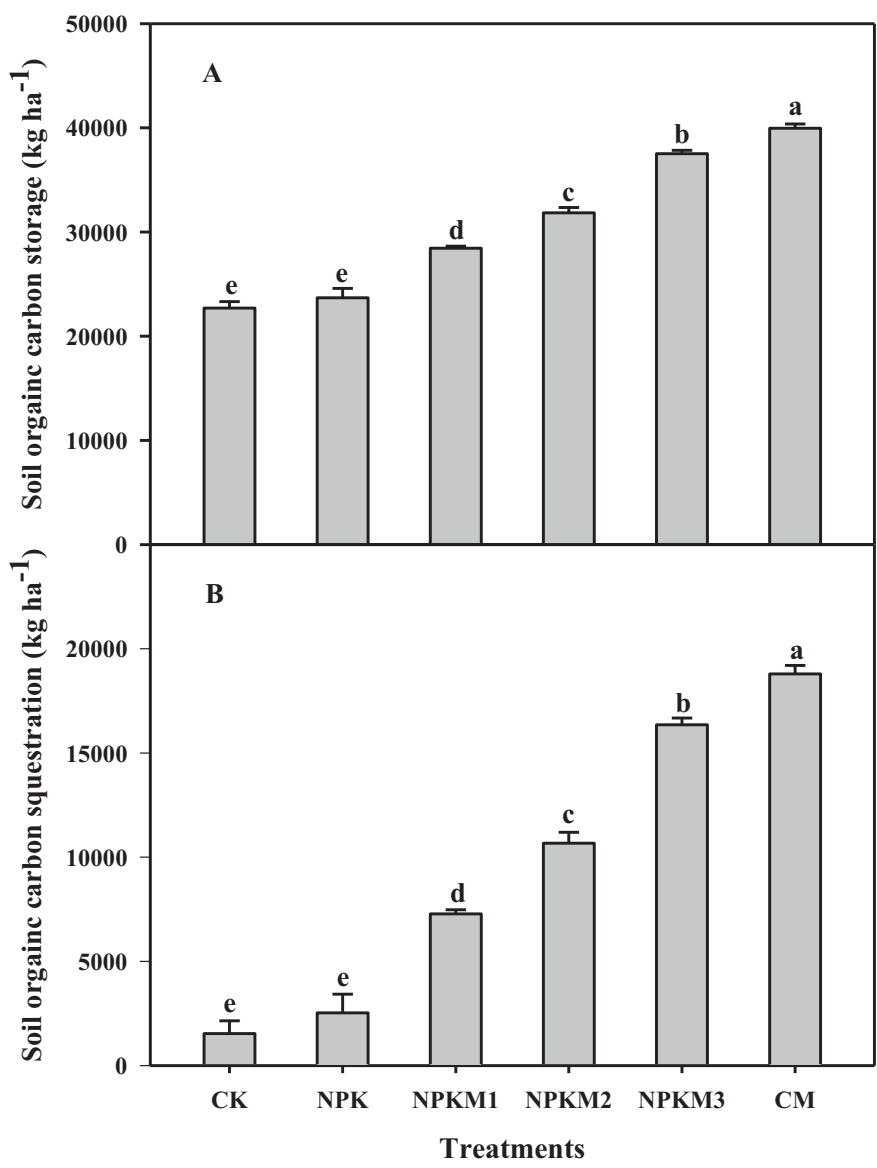

Fig. 2. Soil organic carbon storage (A) and sequestration (B) in topsoil $(0-20 \mathrm{~cm})$ after 5 years' different fertilization treatments. CK, without any fertilizer; NPK, $100 \%$ chemical fertilizer; NPKM1, 25\% cattle manure compost combined with $75 \%$ chemical fertilizer; NPKM2, 50\% cattle manure compost combined with 50\% chemical fertilizer; NPKM3, $75 \%$ cattle manure compost combined with $25 \%$ of chemical fertilizer; CM, $100 \%$ cattle manure compost. Values are reported as means \pm standard deviations, $n=3$. Bars with different letters in the same graph show significant differences at $P \leq 0.05$. came from root biomass and CMC (Table 2). After 5 years of fertilizer managements, the SOM in all plots increased. However, for NPK and CK, the SOM increased slightly, with the former being higher. A 9-year experiment (2000-2008) indicated that long-term mineral fertilizer applications slightly increased SOM content in the same plot, however SOM decreased in plots without fertilizer application (Celik et al., 2010). It was once reported that carbon input was significantly increased from root biomass under the $\mathrm{N}$ treatment compared with the CK; however, neither organic carbon concentration nor carbon storage was significantly changed under the merely $\mathrm{N}$ treatment (Lou et al., 2011). These results indicate that root biomass as carbon source input does not significantly affect the changes in the soil organic carbon storage. Nevertheless, still some argued that significant increases in organic carbon concentration or storage might also happen under chemical $\mathrm{N}$ fertilization alone management (Verma and Sharma, 2007; Olsson et al., 2005; Purakayastha et al., 2008). Those differences seem to mainly depend on the added $\mathrm{N}$ rate, the crop residue management and the tillage regime (Raun et al., 1998; Su et al., 2006).

In our investigation here, significant and positive correlations were noted between CMC and SOM (Table 3), indicating the carbon supplementation occurred to soil with the manure compost. CMC alone or combined with CF significantly increased SOM, which generally increased before the soil is C-saturated (Table 2 and Fig. 2). Therefore, organic manure might be the most important carbon source to restore SOM.

\subsection{Soil bulk density and soil water content}

Organic materials have low bulk density and higher porosity, so the mixing of organic materials with denser mineral fractions of soils causes a decrease in bulk density (Martin and Stephens, 2001; Bronick and Lal, 2005). Decrease in bulk density and increase in SOM with organic fertilizer applications have been also reported in different soils at different application rates (Zebarth et al., 1999). However, most of former investigators did not consider the total $\mathrm{N}$, $\mathrm{P}, \mathrm{K}$ from the organic manure and inorganic fertilizer uniform

Table 3

Pearson correlations of soil organic matter, soil bulk density, soil water content, soil total $\mathrm{N}$ content and earthworm density with cattle manure compost input after 5 years' fertilization managements respectively.

\begin{tabular}{lcc}
\hline & Soil layer & Correlation coefficient \\
\hline Soil organic matter & $0-20 \mathrm{~cm}$ & $0.989^{\mathrm{a}}$ \\
Soil bulk density & $0-10 \mathrm{~cm}$ & $-0.939^{\mathrm{a}}$ \\
& $10-20 \mathrm{~cm}$ & $-0.965^{\mathrm{a}}$ \\
Soil water content & $0-10 \mathrm{~cm}$ & $0.840^{\mathrm{a}}$ \\
& $10-20 \mathrm{~cm}$ & $0.870^{\mathrm{a}}$ \\
Soil total N content & $0-20 \mathrm{~cm}$ & $0.872^{\mathrm{a}}$ \\
earthworm density & $0-20 \mathrm{~cm}$ & $0.950^{\mathrm{a}}$ \\
\hline
\end{tabular}

\footnotetext{
a Correlation is significant at the 0.01 level (2-tailed).
} 
among treatments. We here conducted the experiment on the base of the same total $\mathrm{N}, \mathrm{P}, \mathrm{K}$ application rate, thus proved the functioning of organic manure in decreasing soil bulk density more clearly.

Different fertilizer managements significantly $(P \leq 0.05)$ altered the soil bulk density at either soil depth $0-10 \mathrm{~cm}$ or $10-20 \mathrm{~cm}$. The lowest soil bulk density $\left(1.33 \mathrm{~g} \mathrm{~cm}^{-3}\right)$ was observed at $0-10 \mathrm{~cm}$ depth with only CMC application, while application of merely CF had no significant effect on bulk density. The more CMC and less CF applied, the lower soil bulk density became (Fig. 3). Our findings confirmed that on the base of the same total N, P, K application rate, soil bulk density is significantly and inversely related to the changes in CMC input (Table 3). The effects of organic fertilizers alone or combined with CF were similar at $10-20 \mathrm{~cm}$ depth, except that $C F$ resulted in statistically $(P \leq 0.05)$ lower bulk density value than that of unfertilized soil (Fig. 3 ), which may be due to higher root biomass in the well-fertilized soils.

The 5 years fertilization treatments also had varying and statistically significant effects on soil water content. The water content in the plots fertilized with $\mathrm{CF}$ alone was the lowest at both soil depths $(0-10 \mathrm{~cm}$ and $10-20 \mathrm{~cm})$ (Fig. 4). It increased along with the ratio of CMC input increased, with a series being $\mathrm{CM}>\mathrm{NPKM} 3>$ NPKM2 $>$ NPKM1 $>$ NPK. The water content in the plots only fertilized with $\mathrm{CMC}$ was the highest, and significantly differenced $(P \leq 0.05)$ with $\mathrm{CK}$ and NPK (Fig. 4). Application of CF alone

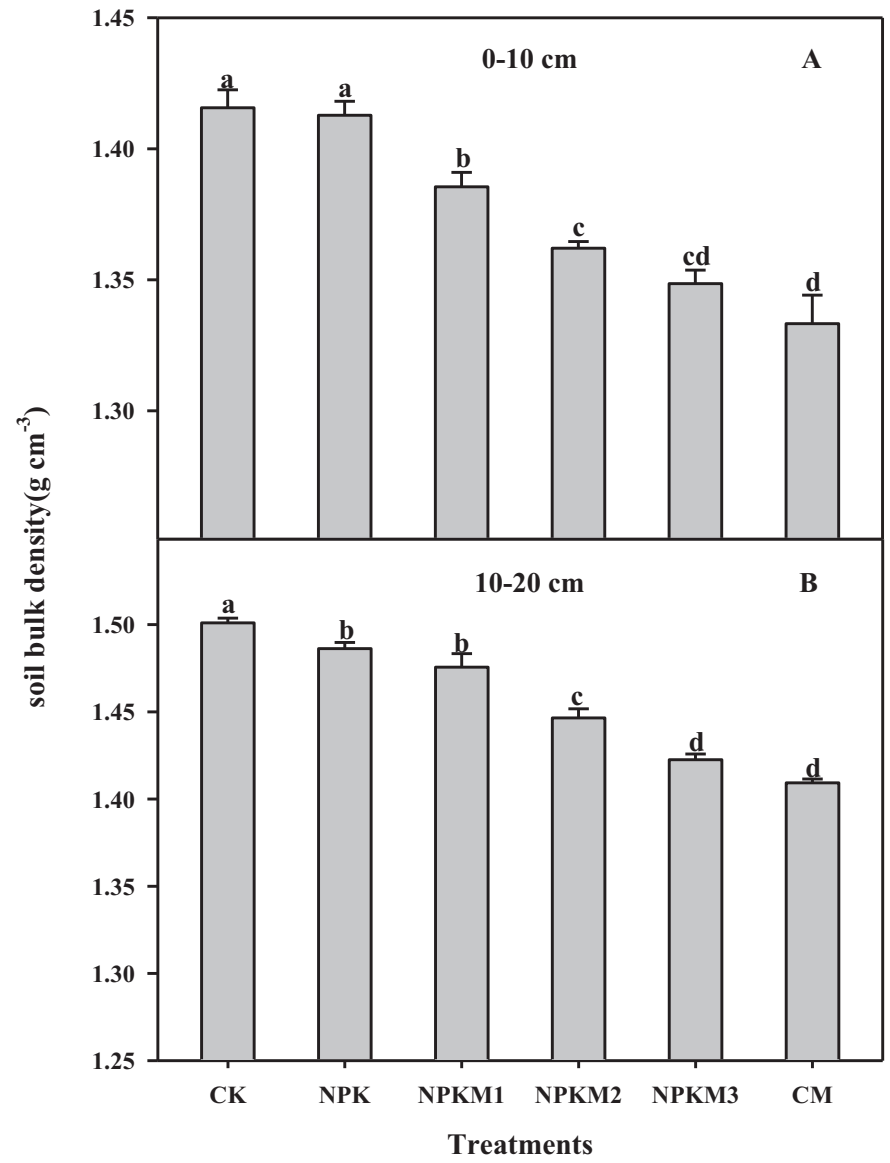

Fig. 3. Soil bulk density in $0-10 \mathrm{~cm}$ and $10-20 \mathrm{~cm}$ soil depth after 5 years' different fertilization treatments. CK, without any fertilizer; NPK, $100 \%$ chemical fertilizer; NPKM1, 25\% cattle manure compost combined with $75 \%$ chemical fertilizer; NPKM2, 50\% cattle manure compost combined with 50\% chemical fertilizer; NPKM3, $75 \%$ cattle manure compost combined with $25 \%$ of chemical fertilizer; CM, $100 \%$ cattle manure compost. Values were reported as means \pm standard deviations, $n=3$. Bars with different letters in the same graph show significant differences at $P \leq 0.05$.

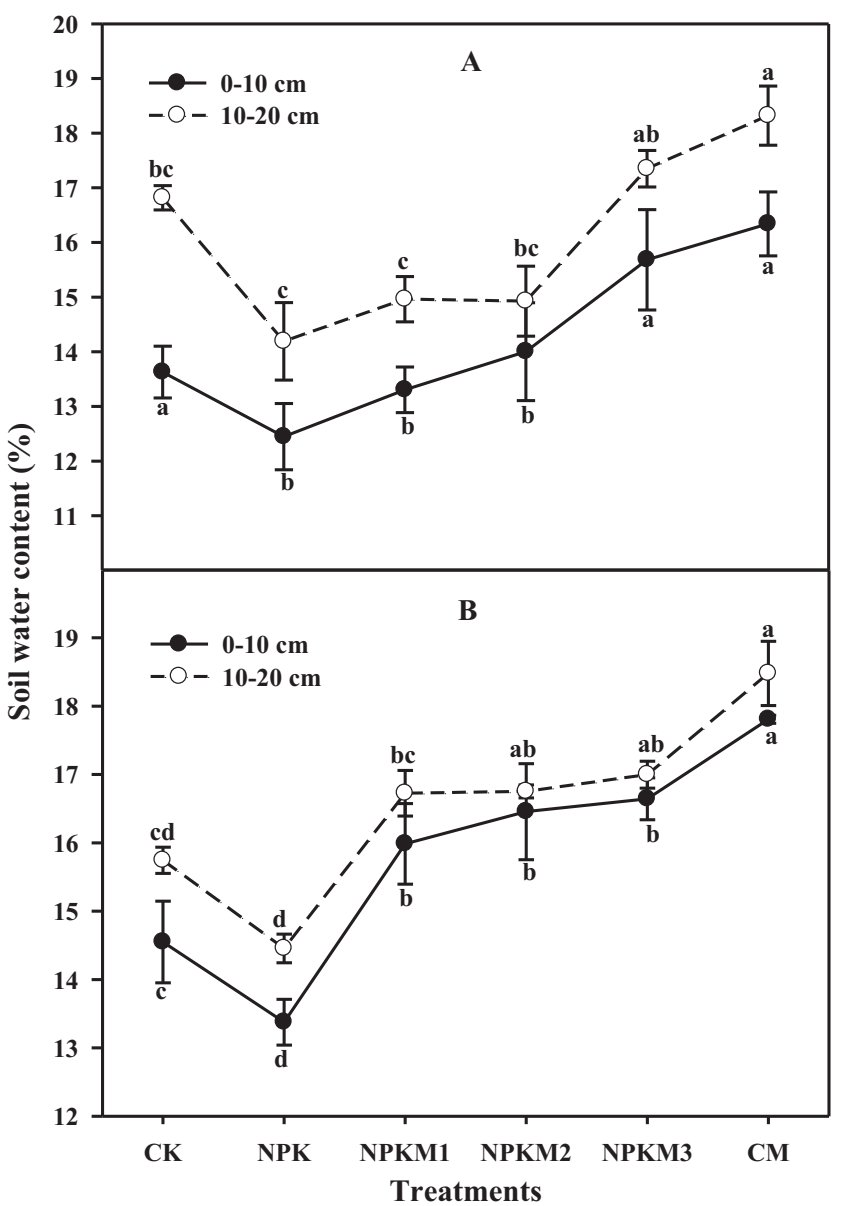

Fig. 4. Soil water content in $0-10 \mathrm{~cm}$ and $10-20 \mathrm{~cm}$ soil depth of different fertilization treatments on 11 June, 2014 (A) and 9 October, 2014 (B). CK, without any fertilizer; NPK, 100\% chemical fertilizer; NPKM1, 25\% cattle manure compost combined with 75\% chemical fertilizer; NPKM2, 50\% cattle manure compost combined with 50\% chemical fertilizer; NPKM3, 75\% cattle manure compost combined with $25 \%$ of chemical fertilizer; $\mathrm{CM}, 100 \%$ cattle manure compost. Values were reported as means \pm standard deviations, $n=3$. Different letters within the same line show significant differences at $P \leq 0.05$.

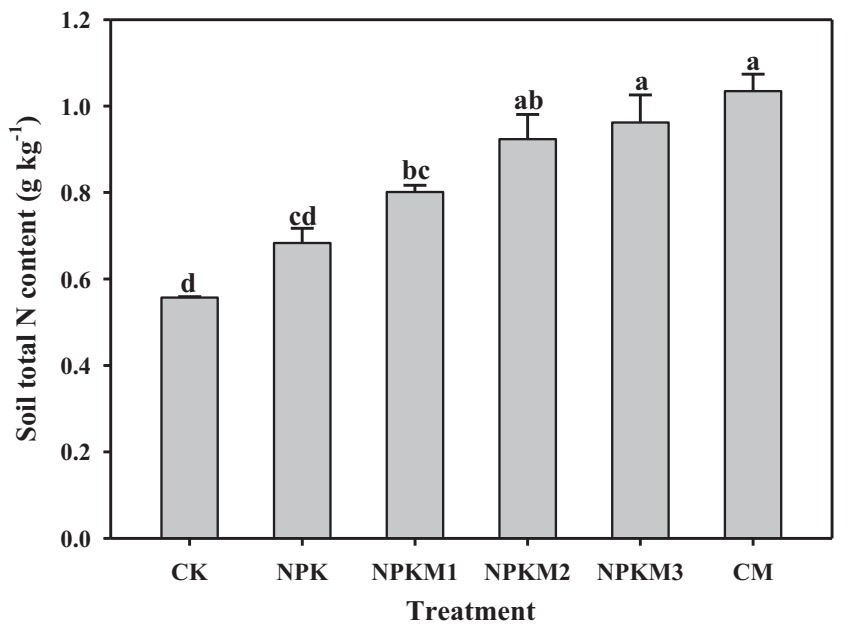

Fig. 5. Soil total $\mathrm{N}$ content in $0-20 \mathrm{~cm}$ soil depth after 5 years' different fertilization treatments. CK, without any fertilizer; NPK, 100\% chemical fertilizer; NPKM1, 25\% cattle manure compost combined with 75\% chemical fertilizer; NPKM2, 50\% cattle manure compost combined with 50\% chemical fertilizer; NPKM3, 75\% cattle manure compost combined with $25 \%$ of chemical fertilizer; $C M, 100 \%$ cattle manure compost. Values were reported as means \pm standard deviations, $n=3$. Bars with different letters show significant differences at $P \leq 0.05$. 

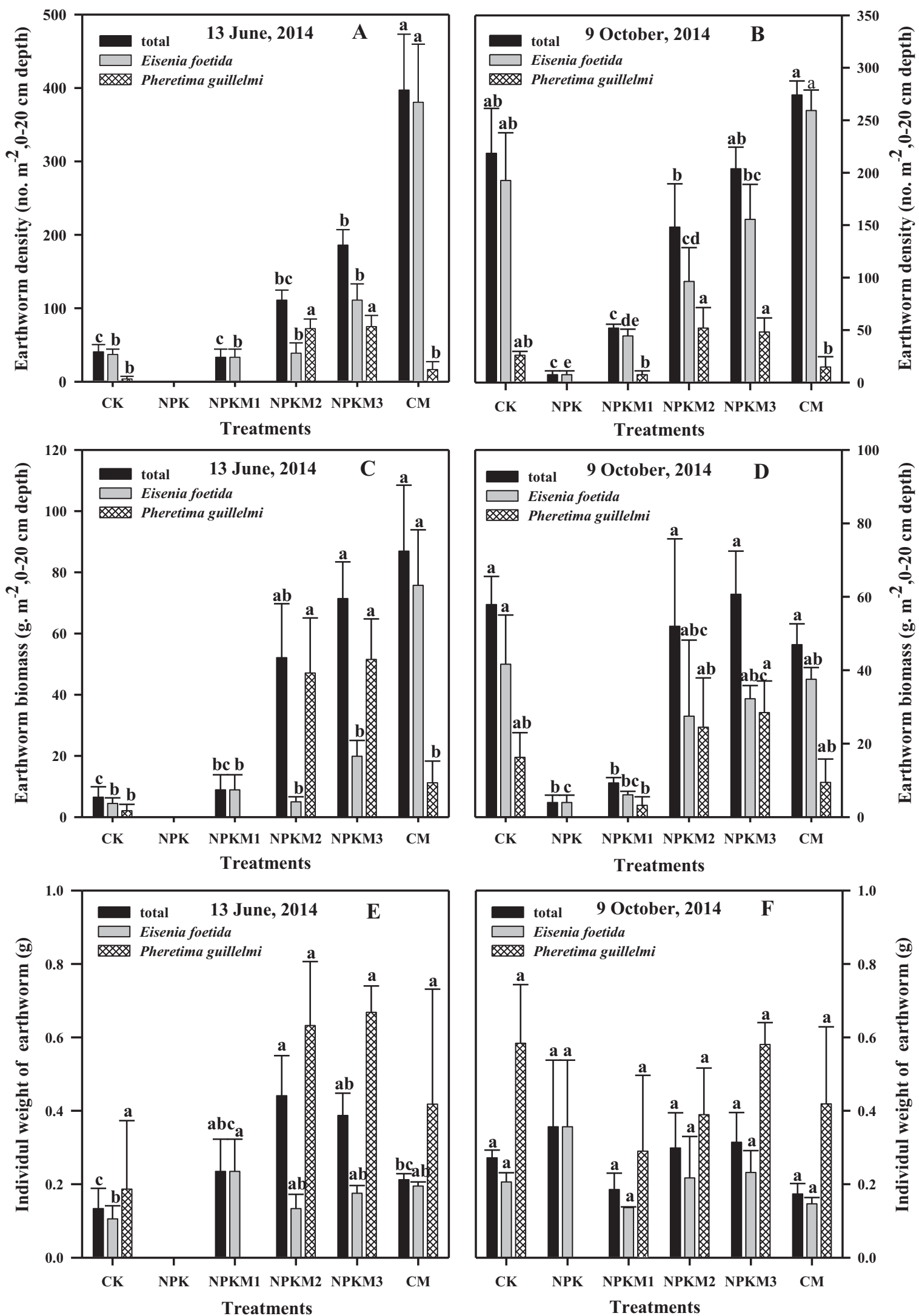

CK NPK NPKM1 NPKM2 NPKM3 CM

Treatments

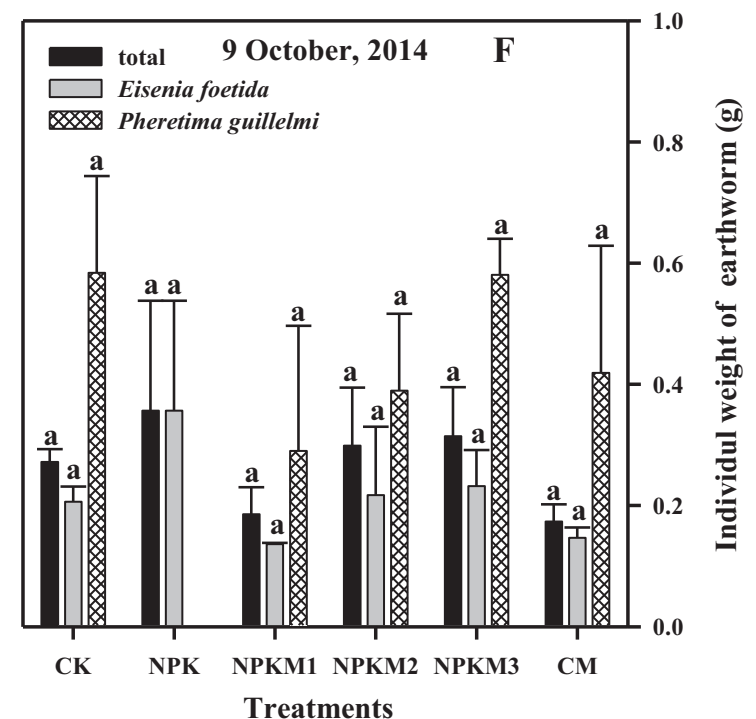

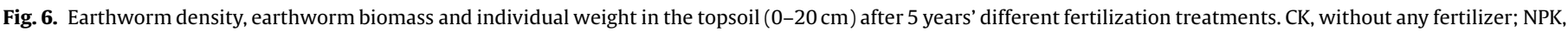

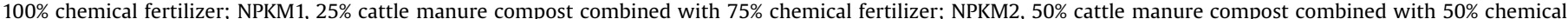

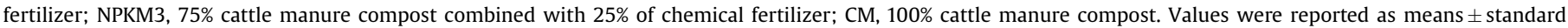
deviations, $n \geq 3$. Bars with same type and different letters in the same graph show significant differences at $P \leq 0.05$. 
decreased the stability of macro-aggregates and moisture retention capacity (Celik et al., 2004; Liu et al., 2013), however, manure application could improve the mean weight diameter of aggregates, total porosity and water holding capacity of soils (Rasool et al., 2008; Karami et al., 2012). Our findings clearly support that animal manure can well improve soil moisture conditions, as noteworthy and positive correlations being found between CMC input and soil water content $(P \leq 0.01)$ (Table 3$)$.

\subsection{Soil total $N$ content}

Fertilizer management also showed statistically significant effect on soil total $\mathrm{N}$ content (Fig. 5). Significant and positive correlation $(P \leq 0.01)$ was also observed between CMC input and soil total $\mathrm{N}$ content (Table 3 ). Without any fertilizer such as in the case of $\mathrm{CK}$, the soil total $\mathrm{N}$ decreased by $24 \%$ compared to the initial value in 2009. The soil total $\mathrm{N}$ in the plots treated with only $\mathrm{CF}$ slightly decreased by $8 \%$. However, the soil total $\mathrm{N}$ in the plots fertilized with CMC alone or combined with CF increased in varying degrees (Fig. 5).

At the same total N, P, K application rate, when the ratio of cattle manure compost increased, the soil total $\mathrm{N}$ in the topsoil $(0-20 \mathrm{~cm})$ also increased, with the trend being $\mathrm{CM}>\mathrm{NPKM} 3>\mathrm{NPKM} 2>$ NPKM1 $>$ NPK. When the ratio of CMC input was more than $50 \%$, the soil total $\mathrm{N}$ content was significantly greater $(P \leq 0.05)$ than those treated with merely $\mathrm{CF}$ (Fig. 5), but the average annual yield in NPK treatment was not significantly greater than these treatments (Table 2). These results indicated that application of organic manure alone or combined with CF could increase nitrogen use efficiency. Our findings are similar with another report lasting six years in the paddy soil derived from Quaternary red clay in Hunan Province of Southern China, which reported that application of organic manure or organic manure combined with $\mathrm{CF}$ could greatly increase nitrogen use efficiency (Xu et al., 2008). This may be partially due to a slow release of $\mathrm{N}$ from manure (Liu et al., 2013) and reducing $\mathrm{N}_{2} \mathrm{O}$ emissions from compost in combined with urea (Ding et al., 2013).

\subsection{Earthworm activity}

We found that fertilizer management had statistically important effect on earthworm density, earthworm biomass, individual weight and species (Fig. 6). There was significant and positive correlation between CMC input and earthworm density $(P \leq 0.01)$ (Table 3).

Two main species, Eisenia foetida and Pheretimaguillelmi, were noted in the plots. Without any fertilizer, there were still some earthworms in the plots, however, after 5 years $\mathrm{CF}(375.0 \mathrm{~kg}$ $\mathrm{Nha}^{-1} \mathrm{yr}^{-1}$, 92.4 $\mathrm{kg} \mathrm{P}_{2} \mathrm{O}_{5} \mathrm{ha}^{-1} \mathrm{yr}^{-1}$ and $316.3 \mathrm{~kg} \mathrm{~K}_{2} \mathrm{Oha}^{-1} \mathrm{yr}^{-1}$ ) alone application, no earthworms were found in the summer surveying (13 June, 2014) and only a few big E. foetida appeared in autumn (9 October, 2014). When the ratio of CMC input increased, the total earthworm density and total biomass, the density and biomass of E. foetida increased correspondingly, with the trend being $\mathrm{CM}>\mathrm{NPKM} 3>\mathrm{NPKM} 2>\mathrm{NPKM} 1>\mathrm{NPK}$. The individual weight of $E$. foetida was found to increase at first, and then decrease. The density, biomass and individual weight of P.guillelmi increased at the beginning, and decreased later on. The density, biomass and individual weight of P.guillelmi were the greatest in NPKM3. These trends were almost the same between both surveying times of June and October (Fig. 6). These results revealed that $\mathrm{CF}$ application alone had negative effects on earthworms, while CMC alleviated such negative effects, with $E$. foetida preferring more manure than P. guillelmi. In CK, earthworm density and biomass and individual weight on 9 October, 2014 were much larger than that on 13 June, 2014. This might because the soil was much wetter during maize growing period (from middle June to October, 2014) than wheat growing period (from October, 2013 to June, 2014), and the wet soil was better for earthworm to grow and reproduce.

A study conducted in a high production field in Huantai County, China's northern plain, reported that the biomass of the earthworm decreased with the application of merely CF (Cao et al., 2004). However, another report found inorganic fertilizers had positive effect on earthworms, which might be realized by increasing the amount of plant biomass, thereby increasing their food supply (Edwards and Lofty, 1982). Decreased CF with increasing organic fertilizer compost resulted in higher SOM content which could increase earthworm activity, and in turn, earthworms increased SOM level by incorporating surface organic manure into the soil (Hendrix et al., 1992; Lee, 1985). Our study confirmed these findings (Table 2 and Fig. 6). It therefore strengthens the importance of organic manure compost application in restoring soil quality especially soil biodiversity.

\section{Conclusions}

On the base of the same total N, P, K application rate, soil organic matter, soil water content, soil total $\mathrm{N}$ content and earthworm density were significantly and positively $(P \leq 0.01)$ related to cattle manure compost (CMC) input, while there was significantly negative correlation between soil bulk density and CMC input. The average annual yield remarkably increased in CMC combined with chemical fertilizer (CF) compared with $\mathrm{CK}$, but showed no significant differences among fertilizer managements. The highest yield occurred in the plots fertilized with $25 \%$ CMC combined with 75\% CF. Applying merely CF not only led to the lower SOM, water content and total $\mathrm{N}$ content, but also had negative effects on earthworm population, while CMC alleviated such effects.

\section{Acknowledgements}

This study was co-supported by the Key Strategic Project of the Chinese Academy of Sciences (KSZD-EW-Z-012-2) and Shandong Province Taishan Scholarship (No. 00523902). We thank all the staffs especially Mr. Jiang Gaoliang, Ms. Zhou Quan'ai and Mr. Jiang Qingli from Hongyi Organic Farm for providing accommodation and the field facilities. We also thank researchers from Shandong Agriculture University who gave us helps during this study.

\section{References}

Abu-Hamdeh, N.H., 2003. Soil compaction and root distribution for okra as affected by tillage and vehicle parameters. Soil Till. Res. 74, 25-35.

Andersen C., (1979). The influence of farmyard manure and slurry on the earthworm population (Lumbricidae) in arable soil. In: Dindal, D.L. (Ed.), Soil Biology as Related to Land Use Practices. Proc. 5th Int. Coll. Soil Zool. in Syracuse, US. USEPA, pp. 325-335.

Blair, N., Faulkner, R.D., Till, A.R., Poulton, P.R., 2006. Long-term management impactions on soil C, N and physical fertility. Part I: Broadbalk experiment. Soil Till. Res. 91, 30-38.

Blake G.R., Hartge K.H., (1986). Bulk density, In: Klute, A. (Ed.), Methods of soil analysis. Part 1, physical and mineralogical methods, 2nd Edition. Agronomy Monograph No. 9. Soil Science Society of America, Madison, WI, pp. 363-375.

Bremner J.M., Mulvaney C.S., (1982). Nitrogen-total, In: Page, A.L., Miller, R.H., Keeney, D.R. (Eds.), Methods of soil analysis. Part 2. Chemical and microbiological properties, 2nd Edition. Agronomy Monograph No. 9. ASA and SSSA, Madison, WI, pp. 595-624.

Bronick, C., Lal, R., 2005. Soil structure and management: a review. Geoderma 124, $3-22$.

Cao, Z.P., Qiao, Y.H., Wang, B.Q., Xu, Q., 2004. Impact of soil fertility maintaining practice on earthworm population in high production agro-ecosystem in North China. Acta Ecol. Sinica 24, 2302-2306 (in Chinese with English abstract).

Carter, M.R., 2002. Soil quality for sustainable land management: organic matter and aggregation interactions that maintain soil functions. Agron. J. 94, 38-47.

Celik, I., Ortas, I., Kilic, S., 2004. Effects of compost, mycorrhiza, manure and fertilizer on some physical properties of a chromoxerert soil. Soil Till. Res. 78 59-67. 
Celik, I., Gunal, H., Budak, M., Akpinar, C., 2010. Effects of long-term organic and mineral fertilizers on bulk density and penetration resistance in semi-arid Mediterranean soil conditions. Geoderma 160, 236-243.

Clements, R.O., Murray, P.J., Sturdy, R.G., 1991. The impact of 20 years' absence of earthworms and three levels of $\mathrm{N}$ fertilizer on a grassland soil environment. Agr. Ecosyst. Environ. 36, 75-85.

Darwish, O.H., Persaud, N., Martens, D.C., 1995. Effect of long-term application of animal manure on physical properties of three soils. Plant Soil 176, 289-295.

Ding, X.L., Zhang, B., Zhang, X.D., Yang, X.M., Zhang, X.P., 2011. Effects of tillage and crop rotation on soil microbial residues in a rainfed agroecosystem of northeast China. Soil Till. Res. 114, 43-49.

Ding, X.L., Han, X.Z., Liang, Y., Qiao, Y.F., Li, L.J., Li, N., 2012. Changes in soil organic carbon pools after 10 years of continuous manuring combined with chemical fertilizer in a Mollisol in China. Soil Till. Res. 122, 36-41.

Ding, W.X., Luo, J.F., Li, J., Yu, H.Y., Fan, J.L., Liu, D.Y., 2013. Effect of long-term compost and inorganic fertilizer application on background $\mathrm{N}_{2} \mathrm{O}$ and fertilizer-induced $\mathrm{N}_{2} \mathrm{O}$ emissions from an intensively cultivated soil. Sci. Total Environ. 465, 115 124.

Doran, J.W., Zeiss, M.R., 2000. Soil health and sustainability: managing the biotic component of soil quality. Appl. Soil Ecol. 15, 3-11.

Edwards, C.A., Lofty, J.R., 1977. Biology of Earthworms, second ed. Chapman and Hall, London, pp. 309.

Edwards, C.A., Lofty, J.R., 1982. Nitrogenous fertilizers and earthworms populations in agricultural soils. Soil Biol. Biochem. 14, 515-521.

Gong, W., Yan, X.Y., Wang, J.Y., Hu, T.X., Gong, Y.B., 2009. Long-term manuring and fertilization effects on soil organic carbon pools under a wheat-maize cropping system in North China Plain. Plant Soil 314, 67-76.

Haynes, R.J., Naidu, R., 1998. Influence of lime fertilizer, and manure application on soil organic matter content and soil physical conditions: a review. Nutr. Cycl. Agroecosyst. 51, 123-137.

Hendrix, P.F., Mueller, B.R., Bruce, R.R., Langdale, G.W., Parmelee, R.W., 1992. Abundance and distribution of earthworms in relation to landscape factors on the Georgia Piedmont, USA. Soil Biol. Biochem. 24, 1357-1361.

IUSS Working Group WRB, 2014. World Reference Base for Soil Resources 2014. International soil classification system for naming soils and creating legends for soil maps. World Soil Resources Reports No. 106. FAO, Rome. ISBN 978-92-5108370-3.

Ju, X.T., Xing, G.X., Chen, X.P., Zhang, S.L., Zhang, L.J., Liu, X.J., Cui, Z.L., Yin, B., Christie, P., Zhu, Z.L., 2009. Reducing environmental risk by improving $\mathrm{N}$ management in intensive Chinese agricultural systems. Proc. Natl. Acad. Sci. U. S. A. 106, $3041-$ 3046.

Karami, A., Homaee, M., Afzalinia, S., Ruhipour, H., Basirat, S., 2012. Organic resource management: impacts on soil aggregate stability and other soi physicochemical properties. Agr. Ecosyst. Environ 148, 22-28.

Lal, R., Follett, R.F., Kimble, J., Cole, C.V., 1999. Managing U.S. cropland to sequester carbon in soil. J. Soil Water Conserv. 54, 374-381.

Lee, K.E., 1985. Earthworms: Their Ecology and Relationships with Soils and Land Use. Academic Press, Sydney.

Leroy, B.L.M., Herath, H.M.S.K., Sleutel, S., De Neve, S., Gabriels, D., Reheul, D., Moens, M., 2008. The quality of exogenous organic matter: short-term effects on soil physical properties and soil organic matter fractions. Soil Use Manage. 24, 139147.

Li, Z.P., Lin, X.X., Che, Y.P., 2002. Analysis for the balance of organic carbon pools and their tendency in typical arable soils of Eastern China. Acta Pedol. Sin. 39, 351 360 (in Chinese with English abstract).

Li, M.L., Gu, J., Gao, H., Qin, Q.J., Liu, M.J., 2007. Effects of different organic fertilizer on plant character, quality and yield of soybean. J. Northwest A\&F Univ. (Nat. Sci. Edit) 35, 67-72 (in Chinese with English abstract).

Li, Z.P., Liu, M., Wu, X.C., Han, F.X., Zhang, T.L., 2010. Effects of long-term chemica fertilization and organic amendments on dynamics of soil organic $\mathrm{C}$ and total $\mathrm{N}$ in paddy soil derived from barren land in subtropical China. Soil Till. Res. 106, 268-274.

Liu, X.B., Han, X.Z., Song, C.Y., Herbert, S.J., Xing, B.S., 2003a. Soil organic carbon dynamics in black soils of China under different agricultural management systems. Commun. Soil Sci. Plan. 34, 973-984.

Liu, X.J., Ju, X.T., Zhang, F.S., Pan, J.R., Christie, P., 2003b. Nitrogen dynamics and budgets in a winter wheat-maize cropping system in the North China Plain. Field Crop. Res. 83, 111-124.

Liu, X.B., Zhang, X.Y., Wang, Y.X., Sui, Y.Y., Zhang, S.L., Herbert, S.J., Ding, G., 2010. Soil degradation: a problem threatening the sustainable development of agriculture in Northeast China. Plant Soil Environ. 56, 87-97.

Liu, C.A., Li, F.R., Zhou, L.M., Zhang, R.H., Y, Jia, Lin, S.L., Wang, L.J., Siddique, K.H.M., Li, F.M., 2013. Effect of organic manure and fertilizer on soil water and crop yields in newly-built terraces with loess soils in a semi-arid environment. Agr. Water Manage. 117, 123-132.
Lou, Y.L., Wang, J.K., Liang, W.J., 2011. Impacts of 22-year organic and inorganic N managements on soil organic $C$ fractions in a maize field, northeast China. Catena 87, 386-390.

Ma, W.C., Brussaard, L., de Ridder, J.A., 1990. Long-term effects of nitrogenous fertilizers on grassland earthworms (Oligochaeta Lumbricidae): their relation to soil acidification. Agr. Ecosyst. Environ. 30, 71-80.

Mäder, P., Fliessbach, A., Dubois, D., Gunst, L., Fried, P., Niggli, U., 2002. Soil fertility and biodiversity in organic farming. Science 296, 1694-1697.

Marinissen, J.C.Y., 1994. Earthworm populations and stability of soil structure in a silt loam soil of a reclaimed polder in the Netherlands. Agr. Ecosyst. Environ. 51, $75-87$.

Martin P.J., Stephens W., (2001). The potential for biomass production on restored landfill caps. In: Bullard M.J., Christian D.G., Knight J.D., Lainsbury M.A., Parker S. R. (Eds.), Aspects of Applied Biology, 65, pp. 337-344.

Martinez, L.J., Zinck, J.A., 2004. Temporal variation of soil compaction and deterioration of soil quality in pasture areas of Colombian Amazonia. Soil Till. Res. 75, 3-18.

Minuto, A, Davide, S., Garibaldi, A, Gullino, M.L, 2006. Control of soil borne pathogens of tomato using a commercial formulation of Streptomyces griseoviridis and solarization. Crop Prot. 25, 468-475.

Nelson, D.W., Sommers, L.E., 1982. Total carbon, organic carbon, and organic matter In: Page, A.L., Miller, R.H., Keeney, D.R. (Eds.), Methods of Soil Analysis. Part 2: Chemical and Microbiological Properties, 2nd Edition. Agronomy Monograph No. 9. ASA and SSSA, Madison, WI, pp. 539-580.

Olsson, P., Linder, S., Giesler, R., Högberg, P., 2005. Fertilization of boreal forest reduces both autotrophic and heterotrophic soil respiration. Global Change Biol. $11,1745-1753$.

Purakayastha, T.J., Rudrappa, L., Singh, D., Swarup, A., Bhadraray, S., 2008. Long-term impact of fertilizers on soil organic carbon pools and sequestration rates in maize-wheat-cowpea cropping system. Geoderma 144, 370-378.

Rasool, R., Kukal, S.S., Hira, G.S., 2008. Soil organic carbon and physical properties as affected by long-term application of FYM and inorganic fertilizers in maizewheat system. Soil Till. Res. 101, 31-36.

Raun, W.R., Johnson, G.V., Philips, S.B., Westerman, R.L., 1998. Effect of long-term N fertilization on soil organic $\mathrm{C}$ and total $\mathrm{N}$ in continuous wheat under conventional tillage in Oklahoma. Soil Till. Res. 47, 323-330.

Riley, H., Pommeresche, R., Eltun, R., Hansen, S., Korsaeth, A., 2008. Soil structure, organic matter and earthworm activity in a comparison of cropping systems with contrasting tillage rotations, fertilizer levels and manure use. Agr. Ecosyst. Environ. 124, 275-284.

Smetak, K.M., Johnson-Maynard, J.L., Lloyd, J.E., 2007. Earthworm population density and diversity in different aged urban systems. Appl. Soil Ecol. 37, 161-168.

Su, Y.Z., Wang, F., Suo, D.R., Zhang, Z.H., Du, M.W., 2006. Long-term effect of fertilizer and manure application on soil-carbon sequestration and soil fertility under the wheat-wheat-maize cropping system in northeast China. Nutr. Cycl. Agroecosyst. 75, 285-295.

Tejada, M., Gonzales, J.L., 2008. Influence of two organic amendments on the soil physical properties, soil loses, sediment and runoff water quality. Geoderma $145,325-334$

Tejada, M., Gonzalez, J.L., Martinez-Garcia, A.M., Parrado, J., 2008. Application of a green manure and green manure composted with beet vinasse on soil restoration: effects on soil properties. Bioresour. Technol. 99, 4949-4957.

Thomas, G.W., Haszler, G.R., Blevins, R.I., 1996. The effect of organic matter and tillage on maximum compactibility of soils using the proctor test. Soil Sci. 161, 502-508.

Verma, S., Sharma, P.K., 2007. Effect of long-term manuring and fertilizers on carbon pools, soil structure, and sustainability under different cropping systems in wettemperate zone of northwest Himalayas. Biol. Fertil. Soils 44, 235-240.

Wu, T.Y., Schoenau, J.J., Li, F.M., Qian, P.Y., Malhi, S.S., Shi, Y.C., Xue, F.L., 2004. Influence of cultivation and fertilization on total organic carbon and carbon fractions in soils from the loess Plateau of China. Soil Till. Res. 77, 59-68.

Xu, M.G., Li, D.C., Li, J.M., Qin, D.Z., Yagi, K., Hosen, Y., 2008. Effects of organic manure application with chemical fertilizers on nutrient absorption and yield of rice in Hunan of southern China. Agr. Sci. China 7, 1245-1252.

Yang, C.M., Yang, L.Z., Ouyang, Z., 2005. Organic carbon and its fractions in paddy soil as affected by different nutrient and water regimes. Geoderma 124, 133-142.

Zebarth, B.J., Neilsen, G.H., Hogue, E., Neilsen, D., 1999. Influence of organic waste amendments on selected soil physical and chemical properties. Can. J. Soil Soc. 79, 501-504.

Zhao, R.F., Chen, X.P., Zhang, F.S., Zhang, H.L., Schroder, J., Römheld, V., 2006. Fertilization and nitrogen balance in a wheat-maize rotation system in North China. Agron J. 98, 938-945.

Zhen, Z., Liu, H.T., Wang, N., Guo, L.Y., Meng, J., Ding, N., Wu, G.L., Jiang, G.M., 2014. Effects of manure compost application on soil microbial community diversity and soil microenvironments in a temperate cropland in China. PLoS One 9, e108555. doi:http://dx.doi.org/10.1371/journal.pone.0108555. 